\title{
A NOVEL EXTRACELLULAR KERATINASE FROM EXIGUOBACTERIUM SP. DG1: ENZYME PRODUCTION AND DEHAIRING APPLICATION
}

\author{
Jajang GUMILAR ${ }^{1 *}$, Lies Mira YUSIATI², Ambar PERTIWININGRUM², Tomoyuki NAKAGAWA ${ }^{3}$, \\ Suharjono TRIATMOJO²
}

\author{
${ }^{1}$ Faculty of Animal Husbandry, Padjadjaran University, Bandung, Indonesia \\ ${ }^{2}$ Faculty ofAnimal Science, Gadjah Mada University, Yogyakarta, Indonesia \\ ${ }^{3}$ United Graduate School of Agricultural Science, Gifu University, Gifu, Japan
}

\begin{abstract}
A NOVEL EXTRACELLULAR KERATINASE FROM EXIGUOBACTERIUM SP. DG1: ENZYME PRODUCTION AND DEHAIRING APPLICATION ABSTRACT. In this research, we determined the optimum conditions for production of extracellular keratinase in Exiguobacterium sp DG1, and showed the possibility of application of the keratinase for sheep skin dehairing process. Strain DG1 showed the highest productivity of the keratinase activity during the growth in sheep hair meal (SHM) medium $(\mathrm{pH} 8)$ containing $10 \mathrm{~g} / \mathrm{L}$ of SHM with aerobic incubation at $27^{\circ} \mathrm{C}$ for 48 hours. Moreover, dehairing process using an extracellular keratinase from strain DG1 decreased several index parameters in the treatment wastes. For example, in the treatment wastes using keratinase from strain DG1, COD and BOD values decreased drastically ( $82.1 \%$ and $73.7 \%$ respectively), compared to chemical dehairing process, and sulfide content was very low (less than $0.01 \mathrm{mg} / \mathrm{L}$ ). These facts indicate that the extracellular keratinase from strain DG1 possesses a great potential of application for green leather tanning industry.

KEY WORDS: keratinase, enzyme production, Exiguobacterium sp. DG1, dehairing
\end{abstract}

\section{O NOUĂ KERATINAZĂ EXTRACELULARĂ DIN EXIGUOBACTERIUM SP. DG1: OBṬINEREA ENZIMEI ȘI APLICAREA ACESTEIA LA} ÎNDEPĂRTAREA PĂRULUI

REZUMAT. În acest studiu s-au determinat condiţiile optime pentru producerea keratinazei extracelulare din Exiguobacterium sp. DG1 şi s-a demonstrat posibilitatea aplicării keratinazei în procesul de îndepărtare a părului de pe pielea de ovină. Tulpina DG1 a prezentat cea mai mare productivitate a activităţii keratinazei în timpul creşterii în mediu cu blană de ovine (SHM) conţinând $10 \mathrm{~g} / \mathrm{ISHM}(\mathrm{pH}$ 8) cu incubare aerobă la $27^{\circ} \mathrm{C}$ timp de 48 de ore. Mai mult decât atât, procesul de îndepărtare a părului utilizând o keratinază extracelulară din tulpina DG1 a condus la scăderea mai multor parametri la tratarea deşeurilor. De exemplu, în cazul tratării deşeurilor care utilizează keratinaza din tulpina DG1, valorile COD şi BOD au scăzut drastic ( $82,1 \%$ şi respectiv $73,7 \%)$, comparativ cu procesul de îndepărtare chimică a părului, iar conţinutul de sulfuri a fost foarte scăzut (sub $0,01 \mathrm{mg} / \mathrm{l})$. Aceste valori indică faptul că keratinaza extracelulară din tulpina DG1 are un mare potenţial de aplicare în industria de tăbăcire ecologică a pielii.

CUVINTE CHEIE: keratinază, producerea de enzime, Exiguobacterium sp. DG1, depărare

\section{UNE NOUVELLE KÉRATINASE EXTRACELLULAIRE D'EXIGUOBACTERIUM SP. DG1: LA PRODUCTION DE L'ENZYME ET SON APPLICATION} DANS L'ÉPILAGE

RÉSUMÉ. Dans cette recherche, on a déterminé les conditions optimales pour la production de kératinase extracellulaire d'Exiguobacterium sp. DG1 et on a montré une possibilité d'application de la kératinase dans le processus d'épilage de la peau de mouton. La souche DG1 a montré la plus grande productivité de l'activité de la kératinase au cours de la croissance en milieu (pH 8) de poils de moutons (SHM) contenant $10 \mathrm{~g} / \mathrm{L}$ de SHM à l'incubation aérobie à $27^{\circ} \mathrm{C}$ pendant 48 heures. De plus, le procédé d'épilage utilisant une kératinase extracellulaire provenant de la souche DG1 a diminué les différents paramètres d'indexation dans les déchets de traitement. Par exemple, dans le cas des déchets de traitement utilisant la kératinase à partir de la souche DG1, les valeurs de DCO et de DBO ont diminué drastiquement $(82,1 \%$ et $73,7 \%$, respectivement) par rapport au processus d'épilage chimique, et la teneur en sulfure a été très faible (moins de 0,01 mg/L). Ces valeurs montrent que la kératinase extracellulaire de la souche DG1 possède un grand potentiel d'application pour l'industrie du tannage écologique du cuir.

MOTS CLÉS: kératinase, production d’enzymes, Exiguobacterium sp. DG1, épilage

\footnotetext{
"Correspondence to: Jajang GUMILAR, Faculty of Animal Husbandry, Padjadjaran University, Bandung, Indonesia, email: j.gumilar@unpad.ac.id
} 


\section{INTRODUCTION}

Keratins are structural proteins located in skin and its appendages such as hair, nails, feathers and also in epithelial tissues within the body, and most of them are insoluble in water and hardly biodegradable [1]. The stability of keratin depends on tightly packed in the $\alpha$-helix ( $\alpha$-keratin) or $\beta$-sheet ( $\beta$-keratin) into a supercoiled polypeptide chain and its degree of cross linkages by disulfide and hydrogen bonds [2-3]. Keratins are grouped into soft keratin and hard keratin according to the sulfur content. Soft keratins are found in skins and callus; they have a low content of disulfide bonds and are more pliable. On the other hand, hard keratins are found in appendages such as hair, hooves, nails, and feathers, and they have high sulfur content and are tough also inextensible [4].

Generally, keratins are known to be a stable protein, which is resistant to decomposition, and in leather processing industry, hair, which consists of keratins mainly, should be removed from the leather. Leather processing involves four distinct sets of unit operations, i.e. pre tanning, tanning, dyeing, and finishing. During the conventional leather processing by chemical treatment, every unit operations dump specific pollutions. For example, in pre tanning operation especially in conventional dehairing process, they use high proportions of lime and sulfide, these materials are a source of pollution generating large quantities of solid waste [5]. As a result, the waste contains large amounts of chemical oxygen demand (COD), and biological oxygen demand (BOD), it also leads to production of toxic gases, such as hydrogen sulfide [6]. From these backgrounds, various efforts have been made to attempt to reduce and replace the use of $\mathrm{Ca}(\mathrm{OH})_{2}$ and $\mathrm{Na}_{2} \mathrm{~S}$, which are the main chemical ingredients in conventional dehairing process. Hence, several researchers in the leather industry have been actively involved in the development of enzyme base for dehairing, defleshing, and fiber opening processes to replace conventional process [7-8].

The keratinases (EC 3.4.99.11) belong to the group of hydrolases, and are large serine or metalloproteases which are capable of degrading the structure of keratinous proteins [9]. The keratinases are not normal proteases such as subtilisin, papain, and pepsin [10], and they degrade keratin without damaging other structural proteins such as collagen that are potentially used in the leather industry [11].
Therefore, the keratinases from microorganisms have several purposes especially in the green leather industry, and they are one of the important industrial enzymes, because the enzymes are utilized for hydrolyzing feather, hair, wool, and other components. From these facts, several researchers have tried to find the keratinases from microorganisms, such as several bacteria, actinomycetes and fungi. However, only the keratinase from Bacillus licheniformis has reached commercial level so far [12]. On the other hand, we had newly screened keratinase producing bacteria, Exiguobacterium sp. DG1. The strain was isolated from soil containing sheep hair, obtained at traditional Garut sheep farm in Garut District, West Java Province, Indonesia. There have been no reports that genus Exiguobacterium produces keratinase except for our work, and strain DG1 had enough keratinolytic and low collagenase activity [13]. Therefore, we think that keratinase from strain DG1 has a great potential to be used as an enzyme in dehairing process.

In this research, we aimed to show optimum condition for the keratinase production using keratinase producing bacteria, Exiguobacterium sp. DG1, and to indicate the possibility of application of the keratinase to the enzymatic leather processing.

\section{EXPERIMENTAL}

\section{Material and Method}

\section{Bacterial Strain, Media, and Cultivation}

Exiguobacterium sp. DG1 was used for the keratinase production test in this work.

For enzyme production, strain DG1 cultivated in SHM medium contained $1 \%$ sheep hair meal; as the sole carbon and nitrogen source with minimal mineral containing $0.03 \% \mathrm{~K}_{2} \mathrm{HPO}_{4} ; 0.04 \%$ $\mathrm{KH}_{2} \mathrm{PO}_{4^{\prime}} 0.05 \% \mathrm{NaCl}, \mathrm{pH} 7$ [11-13]. The keratinolytic enzyme was produced in $250 \mathrm{ml}$ Erlenmeyer flasks containing $50 \mathrm{ml}$ culture medium, maintained for $48 \mathrm{~h}$ at $25^{\circ} \mathrm{C}$ and $180 \mathrm{rpm}$.

\section{Enzyme Assay}

The culture medium was filtered and centrifuged for $15 \mathrm{~min}$ at $10.000 \mathrm{rpm}$ and $4^{\circ} \mathrm{C}$. The supernatant was used as crude keratinase enzyme for further analysis. The keratinolytic 
activity was determined by using keratin azure (Sigma-Aldrich, St. Louis, USA) as the insoluble substrate. The enzyme samples $(500 \mu \mathrm{L})$ were incubated in a solution of $5 \mathrm{mg}$ of keratin azure in $500 \mu \mathrm{L}$ of $50 \mathrm{mM}$ sodium phosphate buffer (pH 7.5) [14], for $30 \mathrm{~min}$ at $180 \mathrm{rpm}$ and $30^{\circ} \mathrm{C}$. The absorbance of the supernatant was measured at $595 \mathrm{~nm}$. Control samples were prepared in a similar manner except the enzyme was replaced by sodium phosphate buffer. The assays were conducted in four replicates. One unit of keratinase was defined as the amount of enzyme causing an increase of 0.01 absorbance between the sample and control at $595 \mathrm{~nm}$ in 30 min under the given condition.

\section{Effect of Culture Condition on Keratinase Production}

For optimization of keratinase production by Exiguobacterium sp. DG1, sheep hair meal substrate was used with the following parameters: cultivation times $(12,24,36,48,60$ hours), amount of substrate $(5,10,15,20$, and 25 $\mathrm{g} / \mathrm{L}), \mathrm{pH}$ value $(8,9,10,11$, and 12$)$, temperature $\left(23,25,27,29\right.$, and $\left.31^{\circ} \mathrm{C}\right)$. The treatments were replicated four times.

\section{Dehairing Application}

Dehairing application studies were carried out on Garut Sheep skin salted at the tannery facility of PT. Elco Indonesia Sejahtera (Garut district, West Java province, Indonesia). This study used a combination of $0.25 \% \mathrm{Na} 2 \mathrm{~S}$ with $1 \%$ enzyme [5] compared that of commercial formulations in dehairing process which used $2.5 \% \mathrm{Na}_{2} \mathrm{~S}$. The enzyme was crude enzyme produced by Exiguobacterium sp. DG1.

The skin for histological preparations taken after the dehairing process. The method modified from [15]. The skin was cut $1.5 \times 1.0 \mathrm{~cm}$ with a length parallel to the line of the back, then it was put in a fixative liquid with formaldehyde concentrations of $10 \%(\mathrm{w} / \mathrm{v})$. The skin was dehydrated using alcohol 80 , 95 , and $100 \%(\mathrm{v} / \mathrm{v})$ then it was put in the xylene. Skin was put in paraffin and then was cut crosswise using the microtome. Preparations were fixed with thymol and stained with Mallory method. Furthermore they were observed microscopically to identify: (a) epidermis, (b) hair follicle, and (c) corium / dermis.

The content of COD was analyzed using the method of American Public Health Association
(APHA) (2005) section 5220-B and BOD content was tested by APHA (2005) section 5210-B. The sulfide content was analyzed using Standard Methods For The Examination of Water and Wastewater 2012 (SMEWW-4500-S-D).

\section{Statistic Analysis}

Data were analyzed as completely randomized design. Effects of treatments on enzyme activity were performed using analysis of variance and the difference between treatments was analyzed using Duncan's Multiple Range Test. Every treatment was replicated four times.

\section{RESULTS AND DISCUSSION}

\section{Effect of Culture Condition on Keratinase Production of the Strain DG1}

\section{Cultivation Times}

Exiguobacterium sp. DG1 produces an extracellular keratinase enzyme bearing an ability to degrade sheep hair meal, where the levels of expressed enzyme varied during incubation period of growth. Keratinase enzyme production was observed in the fermentation broth every twelve hours. Bacterial growth increased up to 48 hours incubation time (OD 0.56), after that the growth was relatively decreasing. This is because of the continuing depletion of nutrients and buildup of metabolic wastes resulting in death of the cells [16]. Keratinase enzyme production of the strain also increased up to 48 hours, but after that time, the production was decreased (Fig. 1). Incubation time as long as 48 hours had the highest keratinase production $(4.20 \mathrm{U} / \mathrm{ml})$, and it was significantly different $(P<0.05)$ compared to other incubation times. Optimum keratinase production with incubation time 48 hours in line with keratinase that was produced by $B$. halodurans strain PPKS-2 [16], B. licheniformis ER-15 [17], and Chryseobacterium sp. Kr6 [18]. Generally, the maximum keratinase production was generated during the exponential growth phase or at the end of the stationary phase [19]. 


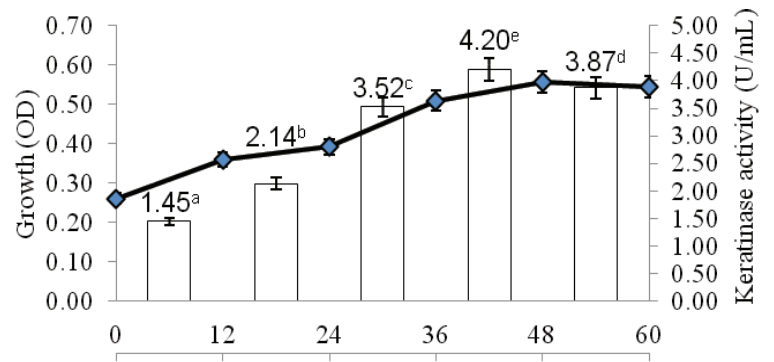

Incubation time (hour)

Figure 1. Effect of incubation times on bacterial growth and keratinase enzyme production.

$a, b, c, d, e$ shows significant differences $(P<0.05)$ among treatments.

\section{Substrate Concentration}

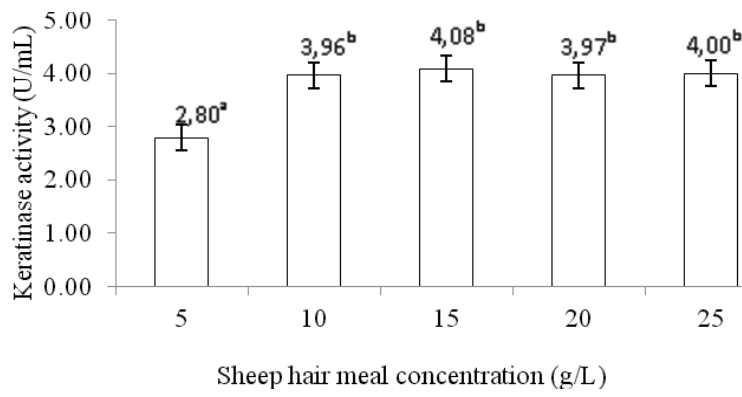

Figure 2. Effect of substrate concentrations on keratinase enzyme production.

${ }^{a, b}$ shows significant differences $(P<0.05)$ among treatments.

Induction levels of keratinase activity during growth of strain DG1 on SHM medium depended on substrate concentrations and cultivation conditions. When substrate concentration was $5 \mathrm{~g} / \mathrm{L}$, the strain showed the smallest keratinase activity $(2.80 \mathrm{U} / \mathrm{mL})$. According to statistic analysis using Duncan Multiple Range Test, the significant difference was lower $(P<0.05)$ than the other concentrations. On the other hand, when substrate concentration was over $10 \mathrm{~g} / \mathrm{L}$, keratinase induction levels did not show any significant difference (Fig. 2). Based on this finding, we could use substrate as much as 10 $\mathrm{g} / \mathrm{L}$ to $25 \mathrm{~g} / \mathrm{L}$. This result was similar with $B$. subtilis KD-N2 that produced highest keratinase activity at $16 \mathrm{~g} / \mathrm{L}$ human hair as a substrate [20] and Bacillus sp. produced the highest keratinase activity in $2 \%$ feather meal as a substrate [21].

Sheep hair meal substrates as carbon, nitrogen, as well as mineral sources were added to the fermentation medium used by Exiguobacterium sp. DG1 as a source of nutrients. Living organisms need nutrients in a certain amount for growth and production. If the sources of nutrients are fewer, then the growth will be disturbed and will not have an optimal production. Giving too much substrate will cause a decrease in the production of keratinase, because the use of the substrate has a limitation. If too much substrate is added, it will cause inhibition and repression on keratinase production. The higher the concentration of the substrate, the higher the viscosity of the medium, so that the mixture of components and air circulation in the medium are hampered by increasing the medium viscosity [22]. Such conditions are very unfavorable for an aerobic bacteria growth.

pH

Many factors affecting to the enzyme productions such as incubation time, $\mathrm{pH}$, temperature, and substrate concentration. This study showed that fermentation condition at $\mathrm{pH}$ 8 induced the highest keratinase activity $(4.06 \mathrm{U} /$ $\mathrm{mL}$ ). The keratinase activity from cells grown at $\mathrm{pH}$ 8 showed a higher significant difference $(P<0.05)$ than that from other $\mathrm{pH}$ grown cells. Otherwise the cells grown at $\mathrm{pH} 12$ showed the lowest keratinase production, then it was lower significant difference $(\mathrm{P}<0.05)$ than other $\mathrm{pH}$ grown cells (Fig. 3 ).

$\mathrm{pH}$ value changes not only affect the nature of the media and substrates, but it also affects bacteria growth and enzyme production. $\mathrm{pH}$ affects several enzymes transport across the cell membrane and reduced access to the substrate, so that the growth in unsuitable conditions limit the speed of growth and enzyme production. The rate of microbial growth fall at a $\mathrm{pH}$ lower or higher than the optimum $\mathrm{pH}$ is due to a change in the three-dimensional proteins structure. Changes in $\mathrm{pH}$ affect the ionization of the $\mathrm{R}$ groups of amino acids in the active site or in other parts of the enzyme, so that the enzyme changes shape and it decreases the enzyme catalytic ability. Changes in the $\mathrm{pH}$ cause denaturation of proteins that decrease the enzyme catalytic activity in the cell. The optimal keratinase enzyme production from bacteria observed at a wide range of $\mathrm{pH}$ started from $\mathrm{pH} 4.5$ until 10 [19]. In this study, the optimal keratinase production was $\mathrm{pH} 8$. This result is 
similar with keratinase produced by Pseudomonas stutzeri [23], Bacillus megaterium F7-1 [22], and Chryseobacterium sp. kr6 [18].

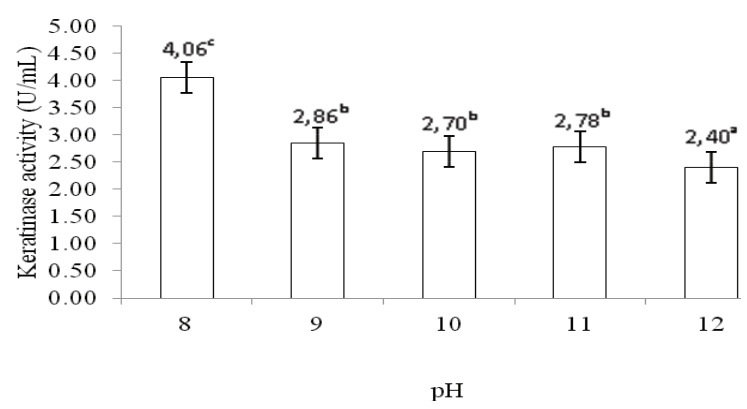

Figure 3. Effect of pH concentrations on keratinase enzyme production.

$a, b, c$ shows significant differences $(P<0.05)$ among treatments.

\section{Temperature}

Referring to the Fig. 4, we can see that the highest production of keratinase enzyme $(4.25 \mathrm{U} / \mathrm{mL})$ was produced at $27^{\circ} \mathrm{C}$ incubation temperature. It was a higher significant difference $(P<0.05)$ than the other treatments. This

\section{Dehairing Application}

This study showed that the sheep skin with enzymatic dehairing used keratinase from Exiguobacterium sp. DG 1 were cleaner, whiter, and brighter, compared to the chemically dehaired skin (Fig 5, A1). This study was in line with the study conducted by [26] that used
Exiguobacterium sp. DG1 is a mesophilic bacteria exhibit the optimal enzyme production and activity ranging from 20 to $30^{\circ} \mathrm{C}$ [24]. Incubation temperature is a characteristic of an organism and profoundly affects the enzyme yield and duration of enzyme synthesis phase. This finding was similar with the optimum temperature of $B$. subtilis KD-N2 [20] and Penicillium spp. [25].

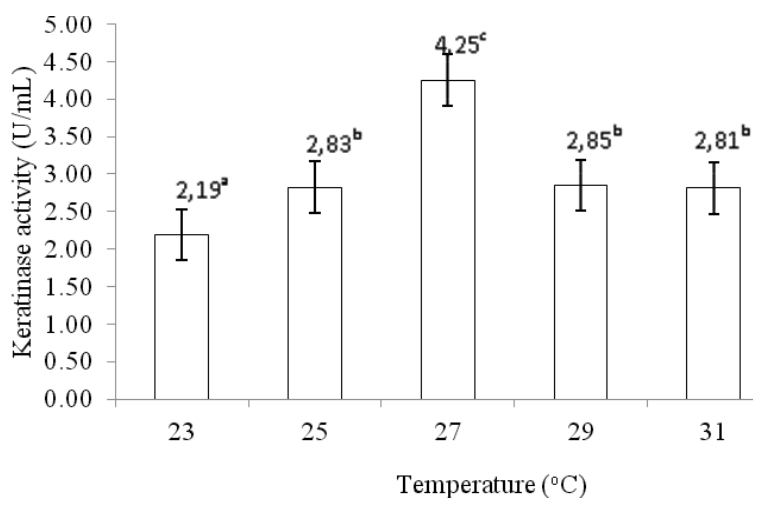

Figure 4. Effect of temperatures on keratinase enzyme production.

$a, b, c$ shows significant differences $(P<0.05)$ among treatments.

enzyme from $P$. aeruginosa in dehairing of buffalo hide. The sheep skin's color changed becoming blue as a result of interaction between $\mathrm{Na}_{2} \mathrm{~S}$ and skin, in chemical dehairing process (Fig $5, A 2)$.

Microscopic analysis of the keratinase treated in dehairing process showed that the epidermis was digested and the hair follicle

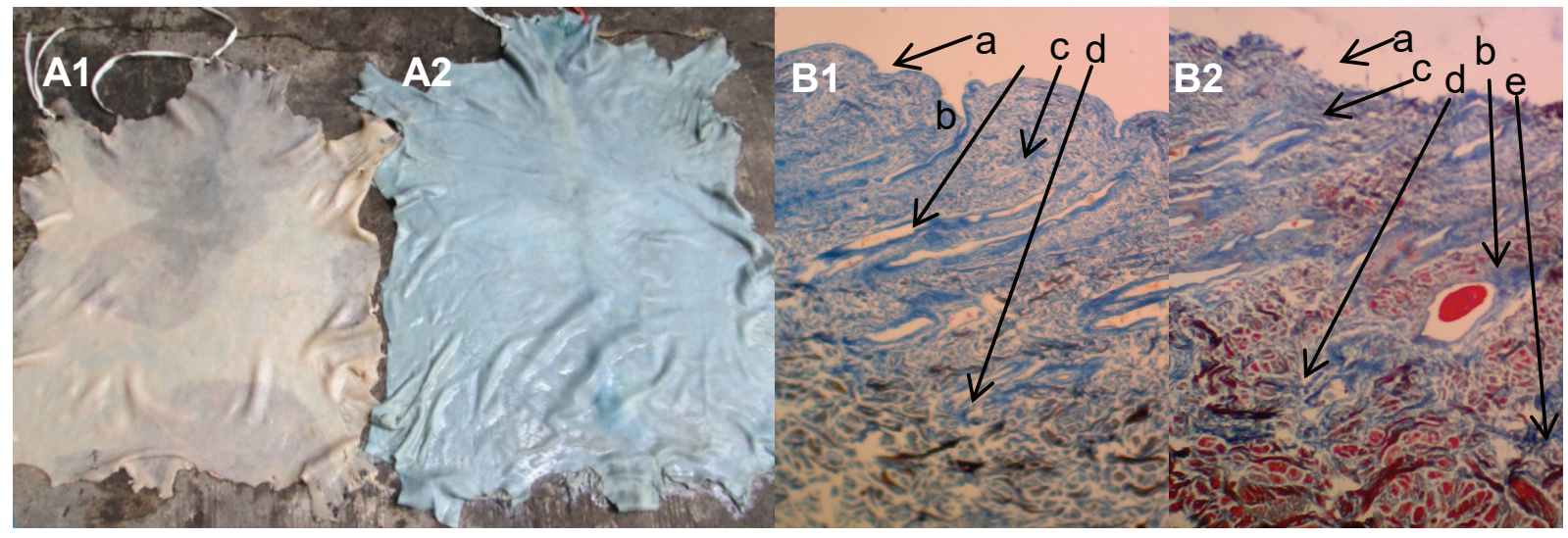

Figure 5. Sheep skin produced by keratinase enzyme dehairing process (A1), and chemical dehairing process (A2). Microscope examination of sheep skin produced by keratinase enzyme dehairing process (B1), and chemical dehairing process (B2). Epidermis (a), folicle (b), collagen / blue (c), elastic tissue / dark brown (d), muscle tissue / orange red (e). 
is empty, it indicates that the hair is loose completely, also the muscle can already be digested (Fig. 5, B1). The use of keratinase in dehairing process has been able to break the soft keratin in the hair follicle so the hair can be detached from the skin. While the use of $2.5 \%$ $\mathrm{Na}_{2} \mathrm{~S}$ treatment showed that the epidermis still remains, appearing rough and not compact, leaving the rest of hair in the follicles root, and the muscle still intact (Fig. 5, B2). Collagen was not damaged, its structure appears to be not modified, and also the elastic tissue may become disorganized, but was still present and was not removed in either the enzymatic dehairing or the chemical dehairing process.

This study showed that the use of $1 \%$ keratinase could already remove the hair perfectly without damaging the collagen network. The use of $1 \%$ crude enzyme from B. cereus MCM B-326 on cow hide enzymatic dehairing also showed good dehairing activity without damaging the collagen and the fibers in the skin were still intact [27]. Enzymatic dehairing on goat skin using enzymes from $B$. subtilis $\mathrm{P} 13$ could remove the epidermis and hair in the follicle perfectly [28].

The hair resulting from this treatment was also different; the hair produced by enzymatic process was still intact, and however the hair produced by a chemical process turned into pulp. Chemical dehairing attacks the hair and reduces it to pulp, meanwhile enzymatic dehairing destroys or modifies the epidermal tissue surrounding the hair bulb, so that the hair is loosened and can be removed mechanically [28].

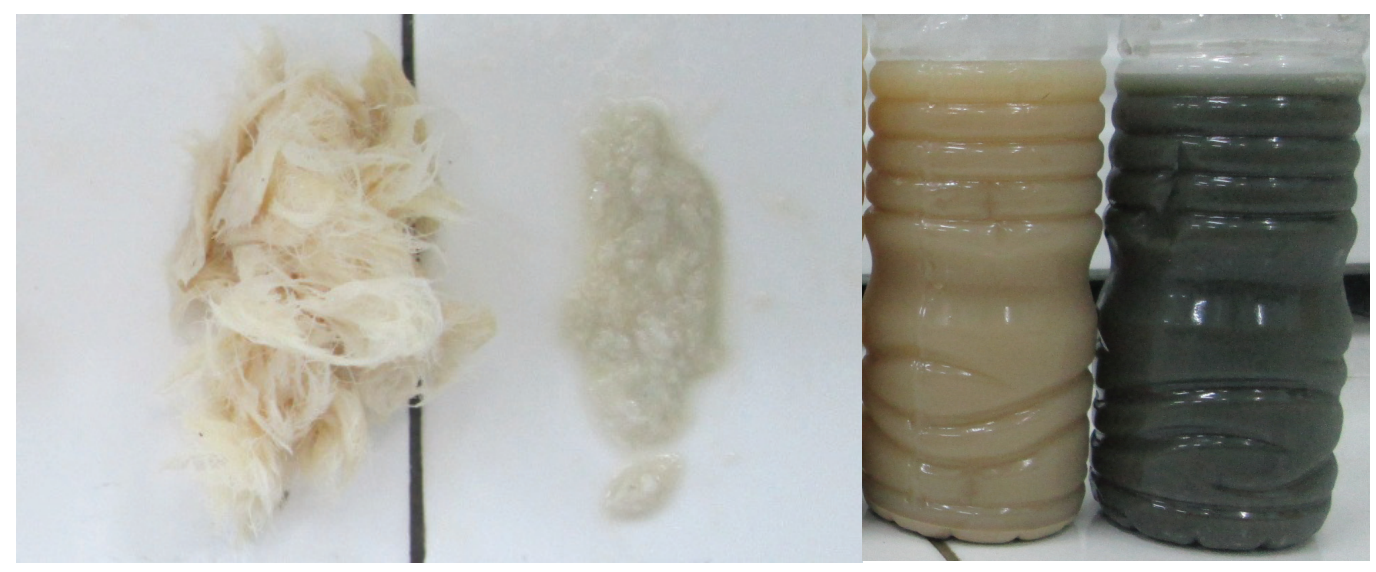

Figure 6. Hair waste produced by keratinase enzyme dehairing process (A1) and chemical dehairing process (A2). Wastewater produced by keratinase enzyme dehairing process (B1) and chemical dehairing process (B2)

Wastewater quality from these treatments had different characteristics. The spent liquor from chemical dehairing and enzymatic dehairing process was collected separately and analyzed for pollution parameter such as COD, BOD, and sulfide content. As compared to the chemical dehairing, the enzymatic dehairing showed reduction of COD from 20.16 to $3.61 \mathrm{~g} / \mathrm{L}$, that is $82.09 \%$; and also of BOD from 4.75 to $1.25 \mathrm{~g} / \mathrm{L}$, that is $73.68 \%$. The keratinase enzyme destroys or modifies the epidermal tissues surrounding the hair bulb, so the hair is loose [28]. Enzymatic dehairing process allows to separate the hair and avoiding the huge semi gelatinous content and high level of organic matter produced by chemical dehairing process in the wastewater [11].

Sulfide content in wastewater generated from the enzymatic dehairing processes was less than $0.01 \mathrm{mg} / \mathrm{L}$, whereas the control that used chemical dehairing process produced an average sulfide waste of $494.25 \mathrm{mg} / \mathrm{L}$. All sulfidein the waste comes from $\mathrm{Na}_{2} \mathrm{~S}$ that used to destroy the hair and breakdown the elements containing sulfides from the dehairing process. Paper [5] stated that almost all the content of sulfide in wastewater was generated in the dehairing process, also [29] stated that the traditional methods of dehairing process using $\mathrm{Na}_{2} \mathrm{~S}$ contribute $100 \%$ of the sulfide waste in leather tanning process.

\section{CONCLUSIONS}

In this work, we showed that Exiguobacterium sp. DG1 is capable of producing 
keratinase enzyme during incubation on the SHM medium ( $\mathrm{pH}$ 8) with $10 \mathrm{~g} / \mathrm{L}$ sheep hair meal at $27^{\circ} \mathrm{C}$ for $48 \mathrm{~h}$. Keratinase produced by Exiguobacterium sp. DG1 could be used in dehairing process and could lead to a reduction of wastewater as much as $82.09 \%$ in COD, $73.68 \%$ in BOD, and less sulfide content $(0.01 \mathrm{mg} / \mathrm{L})$, compared to the chemical dehairing process using natrium sulfide. From these results, it was suggested that keratinase from Exiguobacterium sp. DG1 possesses a great potential of application in the leather tanning industry.

\section{Acknowledgments}

This research was funded by Padjadjaran University and Directorate of Higher Education at The Ministry of Technology, Research, and Higher Education Republic of Indonesia in the program of improving the quality of international publications.

\section{REFERENCES}

1. Friedrich, J., Gradisar, H., Vrecl, M., Pogacnik, A., In vitro degradation of porcine skin epidermis by a fungal keratinase of Doratomyces microsporus, Enzyme Microb Technol, 2005, 36, 455-460, https://doi.org/10.1016/j. enzmictec.2004.09.015.

2. Xie, F., Chao, Y., Yang, X., Yang, J., Xue, Z., Luo, Y., Qian, S., Purification and characterization of four keratinases produced by Streptomyces sp. Strain 16 in native human foot skin medium, Bioresource Technol, 2010, 101, 344-350.

3. Rahayu, S., Syah, D., Suhartono, M.T., Degradation of keratin by keratinase and disulfide reductase from Bacillus sp. MTS of Indonesian origin, Biocatal Agric Biotechnol, 2012, 1, 152-158, https://doi.org/10.1016/j. bcab.2012.02.001.

4. Gupta, R., Ramnani, P., Microba keratinases and their prospective applications: an overview, Appl Microbiol Biotechnol, 2006, 70, 21-33, https://doi.org/10.1007/s00253-0050239-8.

5. Thanikaivelan, P., Rao, J.R., Nair, B.U., Ramasami, T., Progress and recent trends in biotechnological methods for leather, Trends Biotechnol, 2004, 22, 4, 181-188, https://doi. org/10.1016/j.tibtech.2004.02.008.
6. Jaouadi, B., Chaabouni, S.E., Ali, M.B., Messaoud, E.B., Naili, B., Dhouib, A., Bejar, S., Excellent laundry detergent compatibility and high dehairing ability of the Bacillus pumilus cbs alkaline proteinase (SAPB), Biotechnol Bioprocess Eng, 2009, 14, 503-512, https://doi. org/10.1007/s12257-008-0244-8.

7. Thanikaivelan, P., Rao, J.R., Nair, B.U., Ramasami, T., Recent trends in leather making: Processes, problems, and pathways, Environ Sci Tech, 2005, 35, 37-79, https://doi. org/10.1080/10643380590521436.

8. Sundararajan, S., Kannan, C.N., Chittibabu, S., Alkaline protease from Bacillus cereus VITSN04: Potential application as a dehairing agent, J Biosci Bioeng, 2011, 111, 2, 128-133, https://doi.org/10.1016/j. jbiosc.2010.09.009.

9. Agrahari, S., Wadhwa, N., Isolation and characterization of feather degrading enzymes from Bacillus megaterium SN1 isolated from Ghazipur poultry waste site, Appl Biochem Microbiol, 2012, 48, 2, 175-181, https://doi. org/10.1134/S0003683812020020.

10. Yamamura, S., Morita, Y., Hasan, Q., Yokoyama, K., Tamiya, E., Keratin degradation: a cooperative action of two enzymes from Stenotrophomonas sp., Biochem Biophysic Research Com, 2002, 294, 1138-1143, https:// doi.org/10.1016/S0006-291X(02)00580-6.

11. Macedo, A.J., Beys Da Silva, W.O., Gava, R., Driemier, D., Henriques, J.A.P., Termigonu, C., Novel keratinase from Bacillus subtilis S14 exhibiting remarkable dehairing capabilities, Appl Environ Microbiol, 2005, 71, 594-596.

12. Gupta, R., Rajput, R., Sharma, R., Gupta, N., Biotechnological applications and prospective market of microbial keratinases, Appl Microbiol Biotechnol, 2013, 97, 9931-9940, https://doi. org/10.1007/s00253-013-5292-0.

13. Gumilar, J., Triatmojo, S., Yusiati, L.M., Pertiwiningrum, A.,. Isolation, identification and dehairing activity of Indonesian native keratinolytic bacteria Exiguobacterium sp. DG1, Pak J Biotechnol, 2015, 12, 1, 41-48.

14. Wang, S., Hsu, W., Liang, T., Yen, Y., Wang, C., Purification and characterization of three novel keratinolytic metaloproteases produced by Chryseobacterium indologenes TKU014 in a shrimp shell powder medium, Bioresource 
Technol, 2008, 99, 5679-5686, https://doi. org/10.1016/j.biortech.2007.10.024.

15. Zambare, V.P., Nilegaonkar, S.S., Kanekar, P.P., Production of an alkaline protease by Bacillus cereus MCM B-326 and its application as a dehairing agent, World J Microbiol Biotechnol, 2007, 23, 1569-1574, https://doi.org/10.1007/ s11274-007-9402-y.

16. Prakash, P., Jayalakshmi, S.K., Sreeramulu, K., Production of keratinase by free and immobilized cells of Bacillus halodurans strain ppks-2: partial characterization and its application in feather degradation and dehairing of the goat skin, Appl Biochem Biotechnol, 2010, 160, 1909-1920, https://doi.org/10.1007/ s12010-009-8702-0.

17. Tiwary, E., Gupta, R., Medium optimization for a novel $58 \mathrm{kDa}$ dimeric keratinase from Bacillus licheniformis ER-15: Biochemical characterization and application in feather degradation and dehairing of hides, Bioresourece Technol, 2010, 101, 6103-6110, https://doi. org/10.1016/j.biortech.2010.02.090.

18. Riffel, A., Lucas, F., Heeb, P., Brandelli, A., Characterization of a new keratinolytic bacterium that completely degrades native feather keratin, Arch Microbiol, 2003, 179, 258-265, https://doi. org/10.1007/s00203-003-0525-8.

19. Brandelli, A., Daroit, D.J., Riffel, A., Biochemical features of mikroba keratinases and their production and applications, Appl Microbiol Biotechnol, 2010, 85, 1735-1750, https://doi. org/10.1007/s00253-009-2398-5.

20. Cai, C.G., Zheng, X.D., Medium optimization for keratinase production in hair substrate by a new Bacillus subtilis KD-N2 using response surface methodology, I Ind Microbiol Biotech, 2009, 36, 875-883, https://doi. org/10.1007/s10295-009-0565-4.

21. Pandian, S., Sundaram, J., Panchatcharam, P., Isolation, identification and characterization of feather degrading bacteria, Euro J Exp Biol, 2012, 2, 1, 274-282.

22. Park, G.T., Son, H.J., Keratinolytic activity of Bacillus megaterium F7-1, a feather degrading mesophilic bacterium, Microbiological Res, 2009, 164, 478-485, https://doi.org/10.1016/j. micres.2007.02.004.

23. Chaturvedi, V., Bhange, K., Bhatt, R.,
Verma, P., Production of kertinases using chicken feathers as substrate by a novel multifunctional strain of Pseudomonas stutzeri and its dehairing application, Biocatal Agric Biotechnol, 2014, 3, 2, 167-174, https://doi.org/10.1016/j. bcab.2013.08.005.

24. Allpress, J.D., Mountain, G., Gowland, P.C., Production, purification, and characterization of an extracellular keratinase from Lysobacter NCIMB 9497, Lett Appl Microbiol, 2002, 34, 337342.

25. El-Gendi, M.M., Keratinase production by endophytic Penicillium spp. Morsy 1 under solid-state fermentation using rice straw, Appl Biochem Biotechnol, 2009, 162, 780-794, https://doi.org/10.1007/s12010-009-8802-x.

26. Zambare, V.P., Nilegaonkar, S.S., Kanekar, P.P., Production optimization and purification of a novel extracellular protease from Pseudomonas aeruginosa MCM B-327, New Biotechnol, 2011, 28, 2, 173-181.

27. Nilegaonkar, S.S., Zambare, V.P., Kanekar, P.P., Dhakephalkar, P.K., Sarnaik, S.S., Production and partial characterization of dehairing protease from Bacillus cereus MCM B-326, Biores Tech, 2007, 98, 1238-1245, https://doi.org/10.1016/j. biortech.2006.05.003.

28. Pillai, P., Mandge, S., Archana, G., Statistical optimization of production and tannery applications of a keratinolytic serine protease from Bacillus subtilis P13, Proc Biochemis, 2011, 46, 1110-1117, https://doi.org/10.1016/j. procbio.2011.01.030.

29. Srinivas, D., Naik, G.R., Characterization of alkaline thermostable keratinolytic protease from thermoalkalophilic Bacillus halodurans JB 99 exhibiting dehairing activity, Intr Biodeter Biodegr, 2011, 65, 29-35, https://doi. org/10.1016/j.ibiod.2010.04.013.

(C) 2017 by the author(s). Published by INCDTP-ICPI, Bucharest, RO. This is an open access article distributed under the terms and conditions of the Creative Commons Attribution license (http://creativecommons.org/licenses/by/4.0/). 